6. Ясвин В. А. Психология отношения к природе, Москва, 2000. $456 \mathrm{c}$.

7. Ясвин В. А. Образовательная среда: от моделирования кпроектированию. Москва, 2001.365 с.

\section{REFERENCES}

1. Boreiko, V. Ye. \& Podobailo, A. V. (2004). Ekolohichna etyka. Nachalnyi posibnyk [Environmental ethics. Tutorial]. Kyiv, 116p. [in Ukrainian].

2. Deryabo, S. D. (1996). Ekologicheskaya pedagogika i psikhologiya [Environmental pedagogy and psychology]. Rostov-on-Don, 480 p. [in Russian].

3. Deryabo, S. D. (1995). Prirodnyy obekt kak "znachimyy drugoy". [Natural object as "significant other"]. Moscow-Voronezh, 194 p. [in Russian].
4. Pashukova, T. I., Dopira, A. I. \& Diakonov, H. V. (2000). Praktykum iz zahalnoi psykholohii [Workshop on general psychology] Kyiv, 204 p. [in Ukrainian].

5. Pometun, O. (2006). Suchasnyi urok. Interaktyvni tekhnolohii navchannia : nauk.-metod posibnyk [Contemporary lesson. Interactive Learning Technologies: A Scientific Guide]. Kyiv, 192p. [in Ukrainian].

6. Yasvin, V. A. (2000). Psikhologiya otnosheniya $k$ prirode [Psychology attitudes towards nature]. Moscow, 456 p. [in Russian].

7. Yasvin, V. A. (2001). Obrazovatelnaya sreda: ot modelirovaniya $k$ proektirovaniyu [Educational environment: from modeling to design]. Moscow, $365 \mathrm{p}$. [in Russian].

Стаття надійшла до редакції 04.06.2019

УДК 378.147

DOI:

Оксана Морозова, аспірант кафедри технологічної і професійної освіти Глухівського начіонального педагогічного університету імені Олександра Довженка

\title{
ВИЗНАЧЕННЯ ПОНЯТТЯ “КОМПЕТЕНТНІСТЬ": ЗАРУБІЖНИЙ ТА ВІТЧИЗНЯНИЙ ПІДХІД
}

У статті визначено та обтрунтовано поняття “компетентність". Проаналізовано праці британських, американських, російських та вітчизняних науковців, які досліджували иңю тематику. Розкрито різні підходи до тлумачення вищевказаного поняття, а також їх взаємозв 'язок. На основі розглянутих наукових досліджень, бачимо, щуо відбувається постійний перегляд сутності поняття. Ми з'ясували, щцо поняття компетентність вживається найбільше в галузі освіти, особливо у нашій крайні. Тому виявлено першочерговість иього питання у модернізації системи вищої освіти у світлі вимог сучасної концепції.

Ключові слова: компетентність; компетентнісний підхід; концепиії компетентності; американський підхід; британський підхід.

Jim. 18.

Oksana Morozova, Postgraduate Student of the Technological and Vocational Education Department Hlukhiv Oleksander Dovzhenko National Pedagogical University

\section{THE "COMPETENCE" CONCEPT'S DEFINITION: FOREIGN AND UKRAINIAN SUBMISSION}

The article is devoted to the different definitions of the "competence" concept and its justification. It is disclosed the approaches to the interpretation of the definition: American and British. The American approach considers competency like the individual characteristics for competently performing professional activities. The British approach is based on the activity properties. H. Bom, S. Brown, P. Sparrow, A. Mitrani, B. Smith think that the terms "competency" and "competence" are interchangeable. It was paid attention to the interpretation of this definition by international organizations such as UNESCO, UNICEF, the Council of Europe, and European Organization for Economic Cooperation and Development, the International Department of Standards. The experts of the European Union countries give their own definition, revealing it as the ability to apply knowledge and skills that ensure the active using of knowledge in new situations.

It were analyzed the Russian scientists papers who have studied this topic, namely A. Markova, G. Selevko. Also it is devoted considerable attention to the consideration of this definition in the Ukrainian regulatory legal acts. So in the Ukrainian Laws "On Education", "On Higher Education" is submitted proper definition. It was viewed the concept definition of such Ukrainian researchers as A. Dubasenyuk, N. Moiseyuk, N. Sidorchuk, M. Golovan. It was analyzed the interrelation between foreign and Ukrainian approaches to the disclosure of the notion "competency" based on the research of I. Chebotaryova, A. Lokshinoy, S. Kulikovskiy, O. Antonova and L.Maslak. I have given my own generalized complexdefinition of "competency" and it was noted its multidimensionality. We see that there is a constant revision of the concept essence on the basis of the considered 
scientific researches. We found that the "competency" concept is used most often in the educational field, especially in our country. Therefore, the priority of this issue was determined for the modernization of the higher education system in the context of the modern concept requirements.

Keywords: competency, competence approach, concepts of competence, the American approach, the British approach.

П остановка проблеми. На сучасному етапі розвитку системи освіти виникла потреба у покращенні її взаємозв'язку із ринком праці та пошуку шляхів підвищення якості підготовки фахівців до рівня, досягнутого в країнах ЄС. Не викликає сумнівів, що однією $з$ головних передумов сталого соціальноекономічного розвитку країни $\epsilon$ формування відповідного рівня компетентності ії кадрового потенціалу, зокрема підготовка професійно мобільних кваліфікованих робітничих кадрів, що, в свою чергу, потребує якісно нового педагога професійного навчання. Але перш ніж приступати до розгляду особливостей професійної підготовки у сучасних умовах, необхідно розглянути саме поняття компетентності. Адже воно лежить в основі сучасної концепції освіти.

На сьогодні існує велика кількість підходів до розкриття змісту поняття "компетентність" як серед зарубіжних, так і вітчизняних дослідників. Відбувається постійний перегляд його сутності та змісту, тому дуже часто важко зорієнтуватися у цьому різноманітті дефініцій. Тож ми вважаємо за доцільне розглянути взаємозв 'язок цих підходів.

Аналіз наукових досліджень. Аналізу понять “компетентність" і “компетенція", їх класифікації присвячені роботи багатьох зарубіжних дослідників: Р. Бояциса, С. Вудрафа, Л. Спенсера (США), Р. Бома, С. Брауна, П. Спероу, А. Мітрані, Б. Сміта, Дж. Вінтертона (Великобританія), Р. Рое (Нідерланди), Г. Селевка, А. Маркової (РФ). Реалізації компетентнісного підходу на практиці присвячені праці Дж. Андерсона, Р. Глейзера, А. Маслоу, Р. Олпорта, Дж. Равена (Великобританія), Д. Роджерса, С. Торпа, Дж. Кліффорда, Р. Уайта (США).

Серед українських дослідників варто виділити праці О. Дубасенюк, Н. Мойсеюк, Н. Сидорчук, М. Головань. У контексті нашої тематики найбільшої уваги заслуговують дослідження I. Чеботарьової, О. Локшиної, С. Куликовського, О. Антонової та Л. Маслак.

Мета статті полягає у визначенні та обгрунтуванні сутності поняття “компетентність"; аналізі підходів зарубіжних та українських дослідників до його трактування.

Виклад основного матеріалу. Специфіка педагогічної діяльності полягає в тому, що основним знаряддям праці викладача $€$ його власна персона, особистість, яка й визначає результати його практичної педагогічної роботи. Від сучасної вищої школи вимагається запровадження нових підходів до навчання, що будуть забезпечувати поряд з його фундаментальністю розвиток комунікативних, творчих і професійних компетентностей, потреб у самоосвіті на основі потенційної багатоваріантності змісту і організації освітнього процесу. Невід'ємною частиною професіоналізму є професійна компетентність працівника. Поняття “компетентність” та “компетентнісний підхід” найбільше використовуються стосовно освітянськоїдіяльності. Сучасні фахівці у галузі педагогіки та психології розглядають компетентність як володіння відповідними знаннями та здібностями, що дозволяють людині обгрунтовано судити про певну галузь та ефективно діяти в ній.

Розглядом питання компетентності займаються міжнародні організації - ЮНЕСКО, ЮНІСЕФ, Рада Європи, Організація Європейської Співпраці i Розвитку, Міжнародний Департамент Стандартів. Так, експерти країн Європейського союзу визначають поняття компетентності як здатність застосування знання й уміння, що забезпечує активне застосування навчальних досягнень у нових ситуаціях. У доповіді міжнародної комісії з освіти для XXI ст. “Освіта: прихований скарб” Ж. Делор, сформулювавши “чотири стовпи", на котрих грунтується освіта: "Навчитися пізнавати, навчитися робити, навчитися жити разом, навчитися жити", визначив, можна сказати, основні глобальні компетентності. Так, згідно із Жаком Делором, одна 3 них твердить - навчитися робити так, щоб набути не тільки професійної кваліфікації, але і в ширшому сенсі компетентності, яка дає можливість впоратися 3 різноманітними численними ситуаціями і працювати в групі [7].

Так наприклад, британські науковці Р. Бом, С. Браун, П. Спероу, А. Мітрані, Б. Сміт вважають, що терміни “компетентність” і "компетенція" є взаємозамінними. За Дж. Равеном, бути компетентним для людини означає мати набір компетенцій різного рівня $[9,70]$. Р. Бояцис, Дж. Вінтертон та С. Вудраф визначають “компетентність" як особові характеристики індивіда, що зумовлюють максимально високий рівень виконання роботи $[14$, 56]. На думку німецького дослідника X. Шредера компетентність - це готовність, здатність до ефективного спілкування із людьми, 
відповідальність у ставленні до них, мовні навички та професійні знання, а також власне “Я” (Якомпетентність).

У своїх дослідженнях американець Е. Шорт обгрунтовує чотири загальні концепції компетентності: набуття людиною вмінь і навичок для певної діяльності, що не має творчого характеру; компетентність як володіння знаннями, вміннями та навичками; компетентність як ступінь або рівень здібностей, що офіційно вважається достатнім, компетентність визначається як властивість або спосіб буття людини $[16,22]$.

Варто зазначити, що існує два підходи до трактування поняття “компетентність”: американський та британський. У рамках американського підходу компетентність розглядають як характеристики індивіда для компетентного виконання професійної діяльності. Британській підхід базується на властивостях самої діяльності $[13,9]$.

Поняття “компетентність” широко використовуються восвіті, управлінніперсоналом та інших професійних галузях. Наприклад, А. Стуф та його послідовники вважають, що доцільність визначення терміну компетентність зростає, коли відомо, до якої сфери діяльності належать люди, що дають визначення компетентності [17,350].

На думку Д. Дюбуа, компетентність - це типова модель поведінки, що включає в себе знання, навички, образ мислення, які можуть використовуватися по одинці, або в різних комбінаціях для успішного досягнення найвищої ефективності в роботі $[15,245]$. К. Леві-Лубойєр вважає, що “компетентність” відноситься до сукупності принципів поведінки, що дозволяють людині діяти ефективно у будь-якій ситуації [12, 282].

А. Маркова визначає основні сутнісні категорійні ознаки поняття “компетентність": компетентність не зводиться до освіченості; компетентність $€$ поєднанням психічних якостей, які дають змогу діяти самостійно і відповідально; основою суджень про компетентність $€$ оцінювання та вимір кінцевого результату діяльності; компетентність є характеристикою окремої людини і виявляється у результатах іiі діяльності [5, 46].

У працях Г. Селевка знаходимо: “під компетентністю розуміється інтегральна якість особистості, що виявляється в загальній здатності та готовності до діяльності, яка базується на знаннях і досвіді, здобутих у процесі навчання і соціалізації й орієнтованих на самостійну й успішну участь у діяльності” [10, 139].
У процесі тривалих наукових дискусій виділились чотири основні характеристики поняття “компетентність”: використання компетентності завжди відбувається у певному контексті (скажімо, у конкретній навчальній ситуації); компетентність завжди є результатом, вона характеризує те, що може зробити індивід, а не описує чи розповідає про процес, під час якого він набув цю компетентність (наприклад, учень не показує, що саме він уміє, а розповідає “я читав, я писав...”); для вимірювання здатності індивіда користуватися компетентністю потрібні чітко визначені та затверджені стандарти; компетентність $є$ мірою того, що індивід може зробити у конкретно визначений час $[4,21]$.

В Україні сучасна парадигма освіти ставить у центр педагогічної діяльності формування компетентної особистості, результатом якої $є$ готовність та здатність людини реалізувати свої знання і досвід у проблемних ситуаціях. С. Куликовський спирається на думку експертів Ради Європи і зазначає, що компетентності передбачають спроможність особистості сприймати та відповідати на індивідуальні і соціальні потреби; формують комплекс ставлень, цінностей, знань та навичок [3, 92]. Кожна галузь освіти формує своє коло компетентностей, які $є$ метою та результатом навчання молоді в Україні.

У нормативно-правових актах поняття “компетентність” визначається як динамічна комбінація знань, вмінь і практичних навичок, способів мислення, професійних, світоглядних і громадянських якостей, морально-етичних цінностей, яка визначає здатність особи успішно здійснювати професійну та подальшу навчальну діяльність і є результатом навчання на певному рівні вищої освіти (Закон України "Про вищу освіту” від 25.07.2018р.). Зауважується, що набутий комплекс якостей особистості визначає iii здатність успішно соціалізуватися, провадити подальшу навчальну діяльність (Закон України “Про освіту" від 05.09.2017 р.). Ключові компетентності - ті, яких кожен потребує для особистої реалізації, розвитку, активної громадянської позиції, соціальної інклюзії та працевлаштування і які здатні забезпечити життєвий успіх молоді у суспільстві знань (НУШ. Концептуальні засади реформування середньої школи. 27.10.2016). Основою формування ключових компетентностей є досвід здобувачів освіти, їх потреби, які мотивують до навчання, знання та вміння, які формуються в різному освітньому середовищі (школі, родині тощо), різноманітних соціальних ситуаціях і зумовлюють формування ставлення до них (Державний 


\section{ВИЗНАЧЕННЯ ПОНЯТТЯ “КОМПЕТЕНТНІСТЬ”: ЗАРУБІЖНИЙ ТА ВІТЧИЗНЯНИЙПІДХІ}

стандарт початкової освіти: Постанова КМУк від 21.02.2018 p. № 87).

На думку О. Дубасенюк, міжнародна спільнота вважає, що компетентність - це інтегрована характеристика якості особистості, результативний блок, сформований через досвід, знання, вміння, ставлення, поведінкові реакції, або ж спеціально структуровані (організовані) набори знань, умінь, навичок і ставлень, що їх набувають у процесі навчання і які дозволяють людині визначати і розв'язувати, незалежно від ситуації, проблеми, характерні для певної сфери діяльності [8]

Український педагог Н. Мойсеюк вважає, що “компетентність - якість особистості, яка необхідна для якісної продуктивної діяльності в певній сфері” [6, 639]. Вона наголошує, що до складу компетентності входять не абстрактні загальні та предметні вміння та навички, а конкретні життєві, які будуть необхідними людині будь-якого віку чи фаху.

Інші науковці, зокрема Н. Сидорчук, також розглядає компетентність як складну інтегральну характеристику особистості, деталізуючи їі через “"здатність вирішувати проблеми і типові завдання, які виникають у реальних життєвих ситуаціях, у різних сферах діяльності на основі використання знань, навчального й життєвого досвіду відповідно до засвоєної системи цінностей” $[11,80]$.

Багатоаспектно пропонують розглядати компетентність О. Антонова та Л. Маслак: гармонійне, інтегроване, системне поєднання знань, умінь і навичок, норм, емоційно-ціннісного ставлення та рефлексії, що складають мінімальну готовність особистості до вирішення практичних завдань [8, 101].

Комплексно трактує поняття М. Головань, подаючи таке означення: “компетентність - це володіння компетенцією, що виявляється в ефективній діяльності і включає особисте ставлення до предмету і продукту діяльності; компетентність - це інтегративне утворення особистості, що інтегрує в собі знання, уміння, навички, досвід і особистісні властивості, які обумовлюють прагнення, здатність і готовність розв'язувати проблеми і завдання, що виникають в реальних життєвих ситуаціях, усвідомлюючи при цьому значущість предмету і результату діяльності" $[1,29]$.

Згідно думки вітчизняних науковців, компетентність вміщує в себе “...не тільки професійні знання, навички і досвід у спеціальності, але і ставлення до справи, визначені (позитивні) схильності, інтереси і прагнення, здатність ефективно використовувати знання й уміння, а також особистісні якості для забезпечення необхідного результату на конкретному робочому місці у конкретній робочій ситуації’ [2].

Таким чином, проведене нами дослідження дозволило краще зрозуміти неоднозначність трактування поняття “компетентність”. Оскільки британські дослідники вважають терміни “компетентність” та “компетенція” взаємозамінними, це не останню роль зіграло в тому, що в українській педагогіці відмовилися від другого поняття. Як і значна кількість зарубіжних та вітчизняних дослідників ми дотримуємося американського підходу для трактування терміну “компетентність”, вважаючи її характеристикою індивіда для компетентного виконання професійної діяльності. Значний вклад у дану проблематику зробили і російські науковці, здобутки яких вплинули на трактування дефініції в Україні. Отже, визначення поняття “компетентність” поєднує у собі здобутки як зарубіжних, так і вітчизняних дослідників.

Розглянувши різні визначення поняття “компетентність”, ми можемо зробити висновок, що воно має цілісне значення, $є$ інтегрованим особистісним утворенням, системним поєднанням знань, умінь і навичок, відноситься до загального потенціалу особи, яка володіє певними характеристиками (норми, емоційноціннісне ставлення та рефлексія), що визначають ефективність діяльності, виражають достатній рівень його кваліфікації і професійної підготовки.

\section{ЛІТЕРАТУРА}

1. Головань М. С. Компетенція і компетентність: досвід теорії, теорія досвіду. Вища освіта Украӥни. 2008. № 3. С. 23-30.

2. Державні стандарти професійної освіти: теорія і методика: Монографія. За ред. Н. Г. Ничкало. Хмель-ницький, 2002. 334 с.

3. Куликовський С. Генеза поняття “компетентність” у європейській та українській педагогічній науці. Людинознавчі студії. Педагогіка. 2014. № 29(1). С. 92 103.

4. Локшина О. І. Становлення компетентнісної ідеї в Європейській освіті. Реалізація європейського досвіду компетентнісного підходу у вищій школі України: матеріали методологічного семінару. Київ, 2009. С. 1933.

5. Маркова А. К. Психология профессионализма. Москва, 1996. 308 с

6. Мойсеюк Н. Є. Педагогіка. Навчальний посібник. Київ, 2007. 656 с

7. Образование: сокрытое сокровище. Основные положения Доклада Международной комиссии по образованию для XXI века. Издательство ЮНЕСКО, 1996. URL: https://www.ifap.ru/library/book201.pdf(дата звернення: 20.11.2018). 
8. Професійна педагогічна освіта: компетентнісний підхід: монографія. За ред. О. А. Дубасенюк. Житомир, 2011.564 c.

9. Равен Дж. Компетентность в современном обществе: выявление, развитие и реализация. Пер. с анг. Москва, 2002.396 с.

10. Селевко Г. Компетентности и их классификация. Народное образование. 2004. № 4. С. 138-143.

11. Сидорчук Н. Г. Порівняльний аналіз понять “компетенція” та “компетентність” як складних психолого-педагогічних феноменів. Проблеми освіти: збірник наукових праць. Спецвипуск. Вінниця-Київ, 2015. С. 78-81.

12. Чеботарьова I. О. Етимологія поняття компетентність в англомовних джерелах. Наукові записки кафедри педагогіки. 2015. Випуск XXXVIII. C. 278-291.

13. Analysis Report on Competence Services. 2011.54 p.

14. Boyatzis Richard E. The Competent Manager: A Model for Effective Performance. John Wiley \& Sons, Jan 22, 1982. Business \& Economics. 308 p.

15. Dubois D. The competency casebook. Amherst, MA: HRD, \& Silver Spring MD: International Society for Performance Improvement. 1998. $400 \mathrm{p}$.

16. Short E. C. Competence: Inquiries into its Meaning and Acquisition in Educational Settings. Lanham etc.: University Press of America, 1984. Vol. VI. 185 p.

17. Stoof A., Martens R. L., Van Merriлnboer J. J. G. \& Bastiaens, T. J. The boundary approach of competence: a constructivist aid for understanding and using the concept of competence. Human Resource Development review. 2002. № 1, pp. 345-365.

18. Winterton J., Winterton R. Developing Managerial Competence. URL: http://site.ebrary.com/id/ 10071191?ppg=2 (дата звернення: 20.11.2018).

\section{REFERENCES}

1. Holovan, M. S.(2008). Kompetentsiia i kompetentnist: dosvid teorii, teoriia dosvidu [Competence and competency: experience of theory, theory of experience]. Higher education of Ukraine. No. 3. pp. 23-30. [in Ukrainian].

2. Derzhavni standarty profesiinoi osvity: teoriia i metodyka [State standards for vocational education: theory and methodology]. (Ed.). N.H. Nychkalo. Khmelnytskyi, 2002.334 p. [in Ukrainian].

3. Kulykovskyi, S. (2014). Heneza poniattia "kompetentnist" u yevropeiskii ta ukrainskii pedahohichnii nautsi [Genesis concept of "competency" in European and Ukrainian pedagogical science]. Humanity studies. Pedagogy. № 29(1). pp. 92-103. [in Ukrainian].

4. Lokshyna, O. I. (2009). Stanovlennia kompetentnisnoi idei v Yevropeiskii osviti [Formation of a competency idea in European education.]. The European experience realization of the competence approach in the higher school Ukraine: materials of the methodological workshop. Kyiv, 2009. pp. 19-33. [in Ukrainian].
5. Markova A. K. (1996). Psikhologiya professionalizma [Psychology of professionalism]. Moscov, 308 p. [in Russian].

6. Moiseiuk, N. Ye. (2007). Pedahohika [Pedagogy]. Tutorial. Kyiv, 656 p. [in Ukrainian].

7. Obrazovanie: sokrytoe sokrovishche. Osnovnye polozheniya Doklada Mezhdunarodnoy komissii po obrazovaniyu dlya XXI veka (1996). [Education: hidden treasure. The main provisions of the Report of the International Commission on education for the XXI century]. Available at: https://www.ifap.ru/library/ book201.pdf (accessed 20. Nov. 2018). [in Russian].

8. Profesiina pedahohichna osvita: kompetentnisnyi pidkhid [Professional teaching education: a competency approach].(Ed.).O. A. Dubaseniuk. Zhytomyr, 2011. 564 p. [in Ukrainian].

9. Raven, Dzh. (2002). Kompetentnost v sovremennom obshchestve: vyyavlenie, razvitie i realizatsiya [Competency in modern society: identification, development and implementation]. Moscov, 396 p. [in Russian].

10. Selevko, G. (2004). Kompetentnosti i ikh klassifikatsiya [Competences and it's classification]. Public education. No. 4. pp. 138-143. [in Russian].

11. Sydorchuk, N. H. (2015). Porivnialnyi analiz poniat "kompetentsiia" ta "kompetentnist" yak skladnykh psykholoho-pedahohichnykh fenomeniv [Comparative analysis of the "competence" and "competency" concepts as complex psycho-pedagogical appearances]. Problems of education: collection of scientific works. Special issue. Vinnytsia-Kyiv, pp. 78-81. [in Ukrainian].

12. Chebotarova, I. O. (2015). Etymolohiia poniattia kompetentnist $\mathrm{v}$ anhlomovnykh dzherelakh [The etymology of the competency concept in English sources]. Scientific notes of the Department of Pedagogy.Vol. XXXVIII. pp. 278-291. [in Ukrainian].

13. Analysis Report on Competence Services. 2011.54 p. [in English].

14. Boyatzis Richard, E. (1982). The Competent Manager: A Model for Effective Performance. John Wiley \& Sons, Jan 22. Business \& Economics. 308 p. [in English].

15. Dubois, D. (1998). The competency casebook. Amherst, MA: HRD, \& Silver Spring MD: International Society for Performance Improvement. 400 p. [in English].

16. Short, E. C. (1984). Competence: Inquiries into its Meaning and Acquisition in Educational Settings. Lanham etc.: University Press of America. Vol. VI. 185 p. [in English].

17. Stoof A., Martens R. L., Van Merriлnboer J. J. G. \& Bastiaens, T. J. (2002). The boundary approach of competence: a constructivist aid for understanding and using the concept of competence. Human Resource Development review. No. 1, pp. 345-365. [in English].

18. Winterton J., Winterton R. Developing Managerial Competence. Available at: http://site.ebrary.com/id/ 10071191 ?ppg=2 (accessed 20. Nov. 2018). [in English].

Стаття надійшла до редакції 19.06.2019 